\title{
Procyclicality and the Search for Early Warning Indicators
}




\title{
Procyclicality and the Search for Early Warning Indicators
}

\author{
Hyun Song Shin
}




\title{
IMF Working Paper
}

\author{
Research Department
}

\section{Procyclicality and the Search for Early Warning Indicators ${ }^{1}$ \\ Prepared by Hyun Song Shin}

Authorized for distribution by Stijn Claessens

December 2013

\section{This Working Paper should not be reported as representing the views of the IMF.} The views expressed in this Working Paper are those of the author(s) and do not necessarily represent those of the IMF or IMF policy. Working Papers describe research in progress by the author(s) and are published to elicit comments and to further debate.

\begin{abstract}
This paper compares three types of early warning indicators of financial instability - those based on financial market prices, those based on normalized measures of total credit and those based on liabilities of financial intermediaries. Prices perform well as concurrent indicators of market conditions but are not suitable as early warning indicators. Total credit and liabilities convey similar information and perform better as early warning indicators, but liabilities are more transparent and the decomposition between core and non-core liabilities convey additional useful information.
\end{abstract}

JEL Classification Numbers: F34, E44, G01

Keywords: Non-core liabilities, credit cycles, financial stability

Author’s E-Mail Address:hsshin@princeton.edu

\footnotetext{
${ }^{1}$ Presented at the IMF conference on "Financial Crises: Causes, Consequences, and Policy Response", Washington DC, September 14, 2012. I thank Stijn Claessens, Ayhan Kose, Luc Laeven and Fabian Valencia for comments on an earlier draft and Laura Yi Zhao for research support.
} 


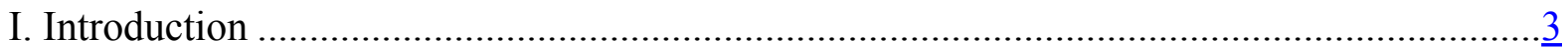

II. Price-based Early Warning Indicators...................................................................

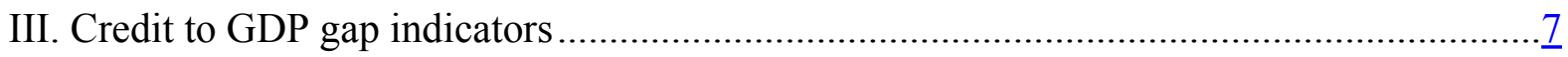

IV. Bank liability aggregates, including some monetary aggregates................................... $\underline{8}$

V. Core and Non-Core Liabilities in China ............................................................

Figure

1. CDS Spreads for Bear Stearns and Lehman Brothers ..................................................

2. Two-Year Changes in Assets, Debt, Equity and Risk-Weighted Assets

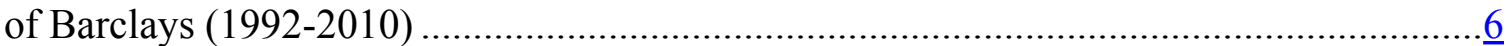

3. Credit to GDP Ratio and GDP Growth for United Kingdom ..........................................

4. Cross-Border Euro-Denominated Assets and Liabilities of Eurozone Banks ..................... 9

5. Monthly Growth Rates of H-P-Filtered Bank Liability Aggregates (Korea and China) ...... 10

6. Structure of Borrowing Relationships for Nonfinancial Corporates in China....................11

7. Hong Kong Banks' Claims and Liabilities to Nonbank Customers

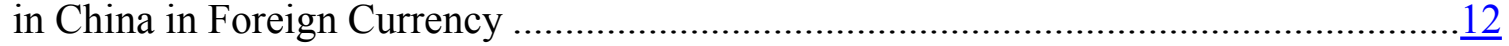

8. Components of China's Monetary Aggregates ........................................................... 13

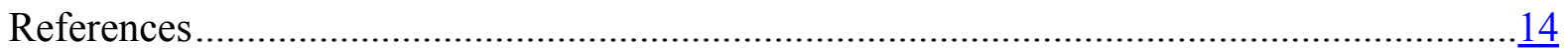




\section{INTRODUCTION}

Finding a set of early warning indicators that can signal the vulnerability to financial turmoil has emerged as a policy goal of paramount importance in the aftermath of the global financial crisis.

There is a large literature on early warning indicators for crises, described well in Chamon and Crowe (2012). The emerging economy crises of the 1990s gave impetus to the work, which has been further developed in the aftermath of the recent global financial crisis that engulfed the advanced economies as well as emerging economies.

The literature to date could be described as being eclectic and pragmatic. It has been eclectic in that the exercise involves appeal to a wide variety of inputs, covering external, financial, real, and fiscal variables, as well as institutional and political factors and various measures of contagion. In their overview of the literature as of 1998, Kaminsky, Lizondo and Reinhart (1998) catalogue 105 variables that had been used up to that date.

The literature has also been pragmatic in that the exercise has focused on improving measures of goodness of fit, rather than focusing on the underlying theoretical themes that could provide bridges between different crisis episodes. ${ }^{2}$

For instance, it has been conventional to distinguish emerging economy crises from those for advanced economies, with a different set of variables entering into the exercise for each category, where emerging economy crises focus on capital flow reversals associated with "sudden stops", for which variables such as external borrowing denominated in foreign currency takes center stage, while for advanced economies housing booms and household leverage take on importance. Claessens, Dell'Ariccia, Igan and Laeven (2010) examine the evidence for the recent financial crisis.

The distinction between emerging and advanced economies is also reflected in the work of the official sector. The IMF has added a new Vulnerability Exercise for Advanced Economies (VEA) to an existing Vulnerability Exercise for Emerging Economies (VEE), which both feed into joint early warning exercise with the Financial Stability Board (FSB). ${ }^{3}$

Although the compartmentalization into emerging and advanced economies helps in improving the goodness of fit, it tends to obscure the common threads that tie together emerging and advanced economy crises. The capital flow reversals in Spain and Ireland in the European crisis have many of the features of a "sudden stop", except that the outflow of

\footnotetext{
${ }^{2}$ The pragmatic focus has also meant that traditional regression techniques (such as the probit model as used in Berg and Patillo (1999)) has given way increasingly to non-parametric techniques that minimize the signal to noise ratio as in Kaminsky, Lizondo and Reinhart (1998). The reason is that non-parametric techniques fare better when there is a large number of explanatory variables.

${ }^{3}$ See IMF (2010) and Chamon and Crowe (2012).
} 
private sector funds has been compensated by the inflow of official funds. ${ }^{4}$ However, since the Eurozone crisis is taking place within a common currency area, the traditional classification of emerging market "currency crises" where currency movements play a key role do not necessarily fit easily in the empirical exercise.

Given the common threads that tie together apparently disparate crises, it can be useful to take a step back from the practical imperatives of maximizing goodness of fit and instead consider the conceptual underpinnings of early warning models. This is the purpose of my paper.

In what follows, I will suggest that the procyclicality of the financial system provides an organizing framework for selecting indicators of vulnerability to crises, especially those that are associated with banks and financial intermediaries more generally.

More specifically, I examine three broad sets of indicators for early warning purposes, and assess their relative likelihood of success. The three sets of indicators are:

- Indicators based on market prices, such as CDS spreads, implied volatility and other price-based measures of default or distress

- Gap measures of the credit to GDP ratio

- Banking sector liability aggregates, including monetary aggregates

To anticipate my conclusions, the first approach (based on market prices) seems most appropriate for obtaining indicators of concurrent market conditions but unlikely to be useful as early warning indicators with enough time for meaningful remedial action.

The credit to GDP gap measure is a distinct improvement from the first as an early warning indicator, with a good pedigree from the work of BIS economists and has been explored extensively as part of the Basel III bank capital rules. Yet, some authors have expressed doubts about its usefulness as a real time measure, or as a measure that yields a threshold that can be applied uniformly across countries.

That leaves the third approach - one based on bank liability aggregates, including various components of the money stock. I will suggest that this third approach is the most promising, as it preserves the advantages of the credit to GDP gap measure but also stands a good chance of yielding indicators that can be used in real time.

The downside, however, of the monetary approach is that any measure derived in this way will need to find meaning by appeal to specific institutional features of the financial system, rather than being applied in an unthinking way.

\footnotetext{
${ }^{4}$ See, for instance, Merler and Pisani-Ferry (2012)
} 
In addition, we will need to transcend traditional thinking behind the definitions of monetary aggregates in order to make the approach useful. Whereas traditional definitions of monetary aggregates exclude the liabilities between financial intermediaries when defining monetary aggregates, such liability aggregates turn out to be perhaps the most informative of them all.

\section{Price-Based EARly Warning Indicators}

Figure 1 gives the CDS spreads of Bears Stearns and Lehman Brothers, with the right hand panel giving the longer perspective and illustrating how the spreads increase sharply with the onset of the crisis.

Figure 1. CDS Spreads for Bear Stearns and Lehman Brothers
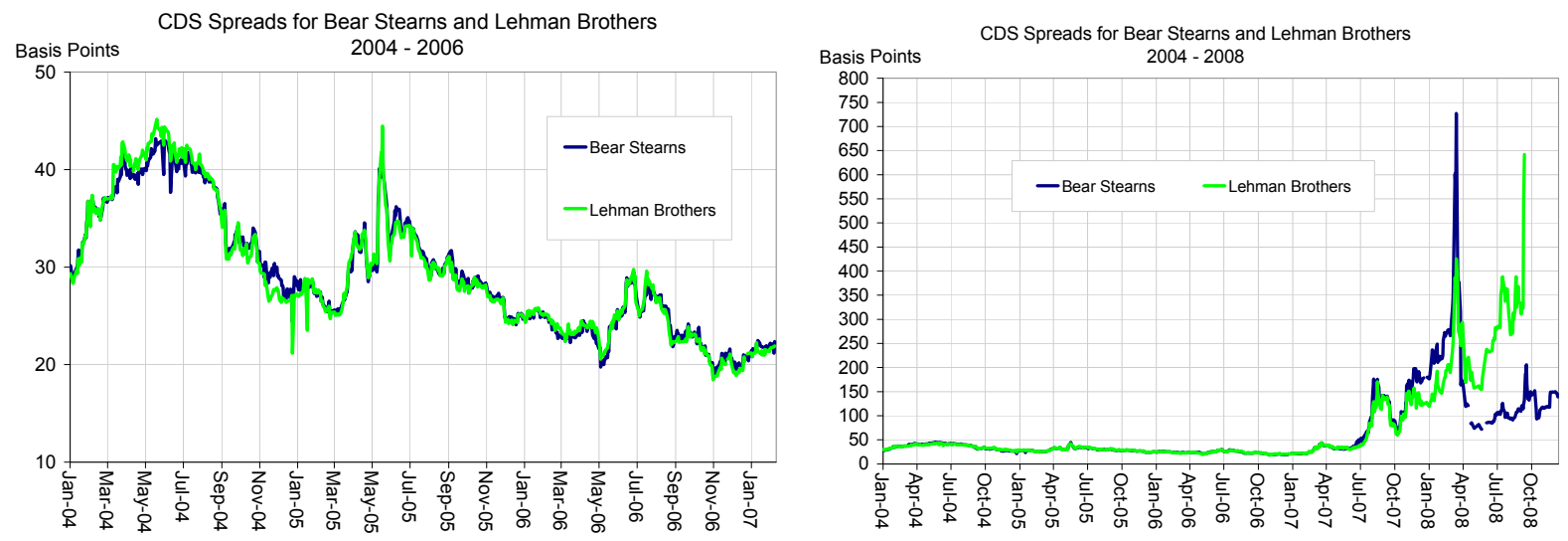

Left panel is for $2004-2006$; Right panel is for $2004-2008$

What is remarkable is how tranquil the CDS measure is before the crisis. There is barely a ripple in the series in the period 2004 to 2006 when the vulnerability to the financial crisis was building up. The left hand panel, which plots the CDS series for the pre-crisis period of January 2004 to January 2007 shows that CDS spreads were actually falling over the period, dipping below 20 basis points at the end of 2006. Other price-based measures, such as Value-at-Risk, implied volatility, structural models of default based on equity prices, etc. all painted the same picture.

The failure of price-based measures of early warning indicators can be traced to their implicit premise that the interaction between market signals and the decisions guided by those signals always interact in a stabilizing virtuous circle, rather than sometimes going astray and acting in concert in an amplifying vicious circle where market signals and decisions guided by those signals reinforce an existing tendency toward procyclicality. Some of the forces toward procyclicality were described in my Mundell-Fleming lecture last year (Shin (2012)). 


\section{Figure 2. Two-Year Changes in Assets, Debt, Equity and Risk-Weighted Assets of Barclays (1992 - 2010)}

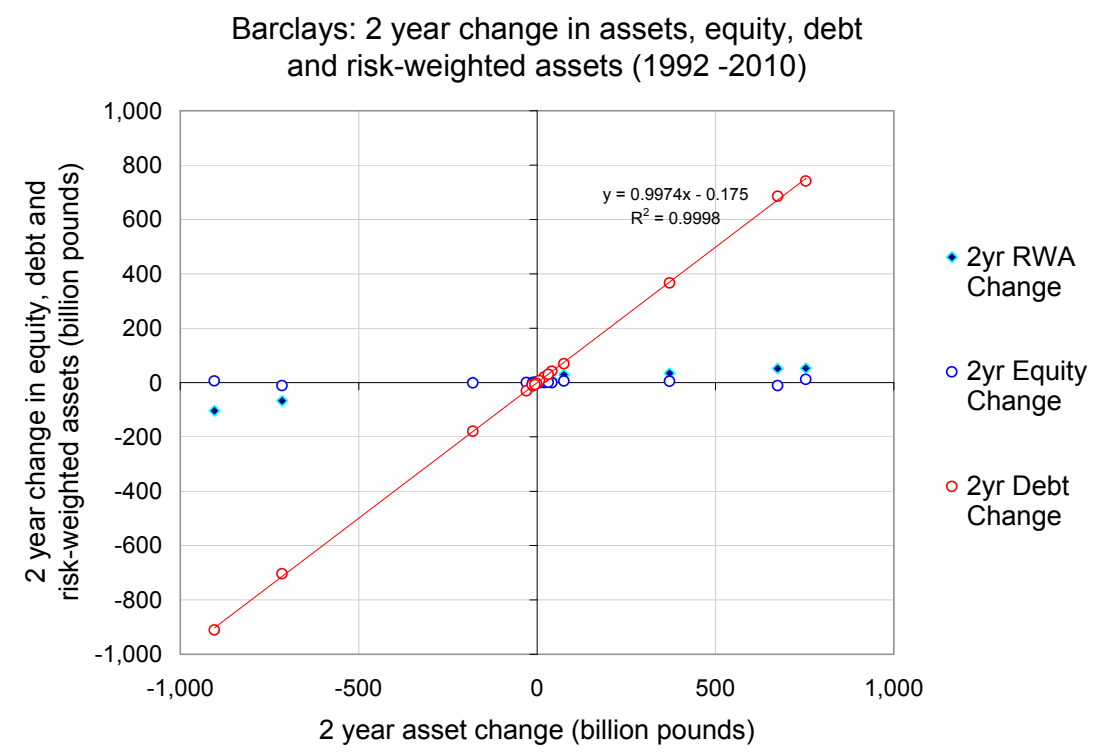

As an illustration of the outcome of such a tendency toward procyclicality, the scatter chart in Figure 2 plots how much the change in the balance sheet size of Barclays - a typical global bank - is financed through equity and how much through debt. It also shows how much riskweighted assets change as the balance sheet grows or shrinks.

The fact that risk-weighted assets barely increase in Figure 2 even as raw assets are increasing rapidly is indicative of the lowering of measured risks (such as spreads or Valueat-Risk measures) during lending booms. Lower measured risks and lending booms thus go together. The causation in the reverse direction will also have been operating - the compression of risk spreads is induced by the rapid increase in credit supply chasing available credits. Such two-way causation lays the ground for a feedback loop in which greater credit supply and the compression of spreads feed off each other.

The procyclicality evident in Figure 2 poses hard challenges for traditional thinking that places faith in market discipline as an integral part of financial regulation, where prices are relied upon to issue timely warning signals. Indeed, Market Discipline was one of the three "Pillars" of the Basel II framework for international bank regulation. Economists associated with the Shadow Financial Regulatory Committee were influential in this regard. Calomiris (1999) argued for rules requiring banks to maintain a minimum amount of subordinated debt, with the rationale being that banks that take on excessive risk will find it difficult to sell their subordinated debts, and will be forced to shrink their risky assets or to issue new equity to comply with the discipline imposed by private uninsured creditors. However, the experience in the run-up to the recent crisis showed how market risk premiums erode so as to nullify market discipline.

Larry Summers's quip (Summers (1985)) that the achievement of finance researchers is to show that "two quart bottles of ketchup invariably sell for twice as much as one quart bottles 
of ketchup" is related to why price-based measures of early warning indicators are likely to fail. Absence of arbitrage means that prices at a point in time are consistent, but they are liable to flip to distress mode (again, fully consistently across assets) with the onset of the crisis. If the task is to give prior warning of the onset of the crisis, price-based measures have little to say about the transition.

Since the onset of crisis is often accompanied by run-like events, the switch from a benign environment to a hostile one can be precipitous. The global games literature illustrates how the transition into financial distress - the "tipping point" - is associated with self-reinforcing effects between individual constraints and market outcomes, but how the onset of the crisis is triggered by apparently small changes in the underlying fundamentals. Outwardly, the switch has the flavor of a self-fulfilling crisis. Goldstein (2010) discusses how empirical research should take account of such tipping points, and shows how the global games framework (Morris and Shin $(1998,2000,2008)$ ) can be usefully invoked in the modeling exercise.

To the extent that market prices have been useful for early warning exercises at all, their usefulness comes precisely when the market price of risk is too low, rather than too high. Thus, it is when asset prices are too high relative to some benchmark that warnings signs are appropriate.

In their 2005 paper on the US housing market, Himmelberg, Mayer and Sinai (2005) argued that a high price-to-rent ratio or high price-to-income ratio need not be indicators of a housing bubble as discount rates implied by low long-term interest rates had also fallen. But since discount rates are prices, the combination of low discount rates and high housing prices is arguably the kind of point-in-time consistency in prices that Summers (1985) had in mind.

\section{CREDIT TO GDP GAP INDICATORS}

Under the Basel III framework, the ratio of credit to GDP takes a central role as the basis for the countercyclical capital buffer. This ratio has been shown to be useful as an indicator of the stage of the financial cycle, notably by Borio and Lowe $(2002,2004)$. To the extent that procyclicality drives financial vulnerability, detecting excessive credit growth is central. Normalizing credit to some underlying flow fundamental measure such as GDP and detecting deviations from trend would be one way to operationalize the notion of excessive credit growth.

However, although a credit boom is clear with hindsight, there are several challenges to using the deviation of the credit to GDP ratio from trend as an early warning indicator in real time.

The first is the difficulty of estimating the trend that serves as the benchmark for what is "excessive" growth. The difficulty is not unique to the credit to GDP ratio, but one shared by other macroeconomic time series. Edge and Meisenzahl (2011) find that ex-post revisions to the credit-to-GDP ratio gap in real time are sizable for the U.S. and as large as the gap itself. The source of the ex post revisions is not the revision of the underlying data, but rather from the revision of the estimated trend measured in real time. 
The second difficulty is that credit growth and GDP dance to somewhat different tunes over the cycle, so that the ratio of the two may sometimes issue misleading signals. Bank lending in particular may be influenced by pre-existing contractual commitments, such as lines of credit, which are drawn down during the crisis. Ivashina and Scharfstein (2010) document the impact of such lines of credit on credit growth during the recent crisis. Therefore, lending may continue to increase for some time after the onset of the crisis.

Figure 3. Credit to GDP Ratio and GDP Growth for United Kingdom
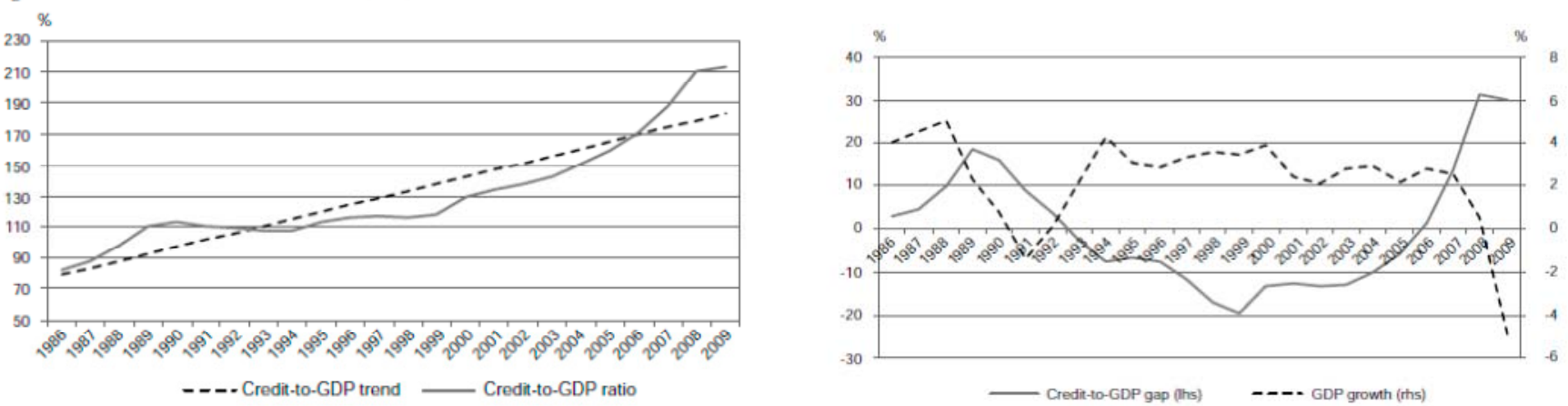

Left hand panel shows UK credit-to-GDP ratio and its time trend (HP filter $\lambda=400,000$ ).

Right panel shows credit-to-GDP gap and GDP growth. Source: Repullo and Saurina (2011).

Figure 3 is taken from Repullo and Saurina (2011) and shows the credit to GDP ratio for the UK and its HP-filtered trend (left hand panel). The HP filter parameter is set at $\lambda=400,000$ as recommended by the Basel Committee, which effectively means a linear trend. The right hand panel shows the credit-to-GDP ratio "gap" between the credit-to-GDP ratio and the trend.

From the right hand panel of Figure 3, we note that the gap measure is large even as GDP growth is falling very sharply during the crisis. Thus, the ratio of the two gives a misleadingly large credit to GDP ratio during the crisis.

Basel III discussions have given a great deal of prominence to the credit-to-GDP gap measure (BCBS $(2009,2010))$. To the extent that the Basel rules are expected to be applied uniformly (or at least, in a consistent manner), finding common thresholds for the credit to GDP ratio would be a basic requirement for Basel III to apply uniformly to all Basel Committee member countries.

\section{BANK LIABILITY AGGREGATES, INCLUDING SOME MONETARY AGGREGATES}

Rapid growth of bank lending is mirrored on the liabilities side of the balance sheet by shifts in the composition of bank funding. As intermediaries who borrow in order to lend, banks must raise funding in order to lend to their borrowers. When credit is growing faster than the available pool of funds that are usually drawn on by the bank ("core liabilities"), the bank will turn to other, "non-core" sources of funding to support its credit growth.

In this way, the ratio of non-core to core liabilities serves as a signal of the degree of risktaking by the bank and hence of the stage of the financial cycle. Hahm, Shin and Shin (2013) 
conduct a cross-country panel probit study and find that the ratio of non-core to core liabilities (especially the non-core liabilities to foreign creditors) emerges consistently the most robust predictor of a currency crisis or credit crisis.

The distinction between core and non-core bank liabilities has a point of contact with monetary aggregates. Traditionally, the importance of monetary analysis for the real economy rested on a stable money demand relationship that underpinned the link between money and macro variables. Money demand is seen as the result of a portfolio decision of economic agents choosing between liquid and illiquid claims, whether based on an inventory holding of money for transactions purposes. For this reason, the traditional classifications of monetary aggregates focus on the transactions role of money as a medium of exchange.

However, unlike commodity money, monetary aggregates are the liabilities of banks and hence have an asset-side counterpart. Recognizing the asset-side counterpart of money and the determinants of bank lending focuses attention on the supply of money by banks. Indeed, rather than speaking of the demand for money by savers, we could turn the relationship on its head, and speak of the supply of funding by savers.

Similarly, by speaking of the supply of money as the demand for funding, the shift in the language serves to focus attention on the banking sector and its balance sheet management over the cycle.

However, monetary aggregates are traditionally measured by netting out claims between banks. For financial stability purposes, however, the claims between banks - especially when they are cross-border - take on great significance.

\section{Figure 4. Cross-Border Euro-Denominated Assets and Liabilities of Eurozone Banks}

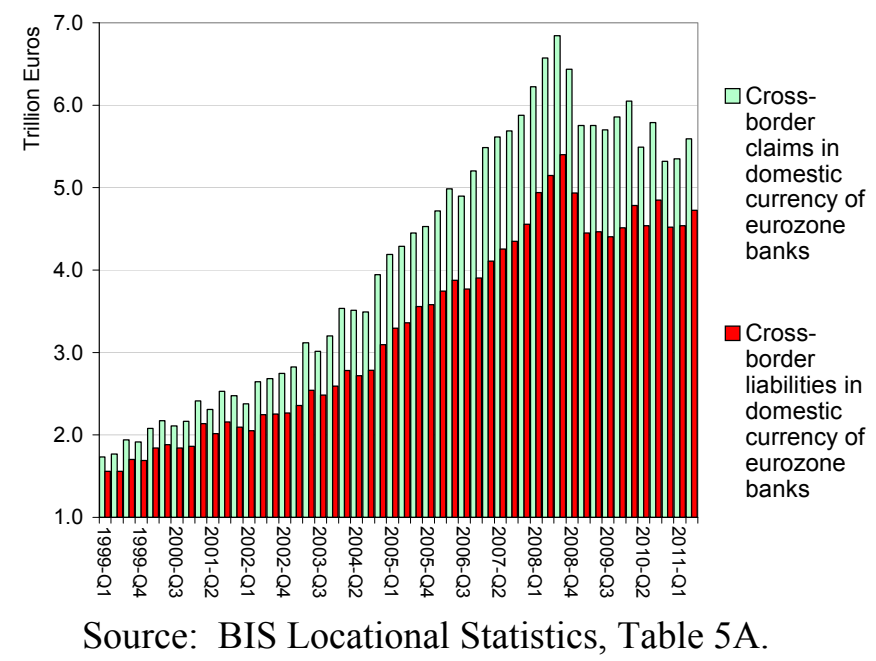

Figure 4 plots the four-quarter growth in cross-border assets and liabilities of eurozone banks in euros. The destination of euro-denominated lending reached outside the eurozone, as eurozone banks expanded into central and Eastern Europe. However, the cross-border eurodenominated liabilities series in Figure 4 is can be seen as non-core liabilities generated through capital inflows. From 1999Q1 to 2008Q3, cross border liabilities rose almost 3.5- 
fold from 1.56 trillion euros to 5.4 trillion euros. This rapid spurt translates into a constant quarterly growth rate of $3.33 \%$, which when annualized is close to $14 \%$.

\section{CORE AND NON-CORE LIABILITIES IN CHINA}

However, what counts as "core" or "non-core" will depend on the financial system and the institutions. For economies with banks operating in developed, open capital markets, noncore funding will typically take the form of wholesale funding of the bank from capital markets, sometimes denominated in foreign currency. However, if the economy has a closed capital account, and when banks are prevented from accessing capital market funding from abroad, then what counts as non-core funding could be quite different.

Compare Korea and China. Figure 5 plots the monthly growth rates of various banking sector liability aggregates for Korea (in the left hand panel) and for China (in the right hand panel). The growth rates have been filtered through a Hodrick-Prescott filter at business cycle frequency. Note that the HP filter is used here with hindsight to highlight differences in time series patterns, not the real-time trend-finding exercise with the Basel III exercise.

\section{Figure 5. Monthly Growth Rates of H-P-Filtered Bank Liability Aggregates for Korea (left panel) and China (right panel) $(\lambda=14400)$}
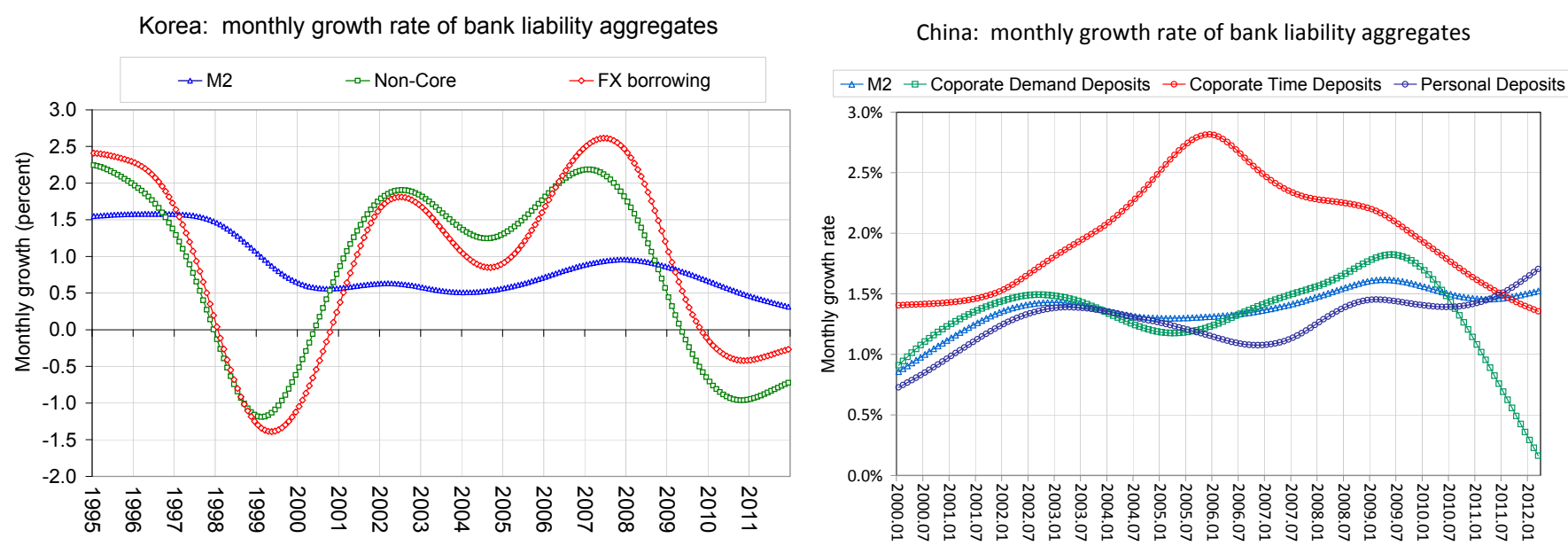

In Korea, banks have access to capital markets, either directly or through the branches of foreign banks operating in Korea. For this reason, the most procyclical components of the bank liability aggregates are those associated with wholesale funding, especially the series for the foreign exchange denominated liabilities of the banking sector. ${ }^{5}$ Before the 1997 Asian financial crisis and the 2008 crisis, non-core liabilities grew rapidly, only to crash with the onset of the crisis. In contrast, the growth of $\mathrm{M} 2$, reflecting household and corporate deposits, is much less variable over the cycle.

\footnotetext{
${ }^{5}$ The other non-core liabilities are bank debentures, repos and other non-deposit items such as promissory notes. See Shin and Shin (2010).
} 
However, the right hand panel of Figure 5 shows that in China, the sub-components of M2 show considerable variation in their time series properties, with corporate deposits showing the tell-tale procyclical patterns as compared to household deposits.

For an economy such as China where banks are prevented from accessing international capital markets in the way that Korean banks do, applying the liability classifications from Korea into "core" and "non-core" would be inappropriate.

Instead, more thought is needed on how financial conditions are transmitted across the border into China. Just as water finds cracks to flow through, even a closed financial system cannot be immune to global financial conditions entirely. This is true especially for a highly tradedependent economy such as China. If the banks are prevented from accessing international capital markets, then the non-financial firms will be the conduit for the transmission of financial conditions.

\section{Figure 6. Structure of Borrowing Relationships for Nonfinancial Corporates in China}

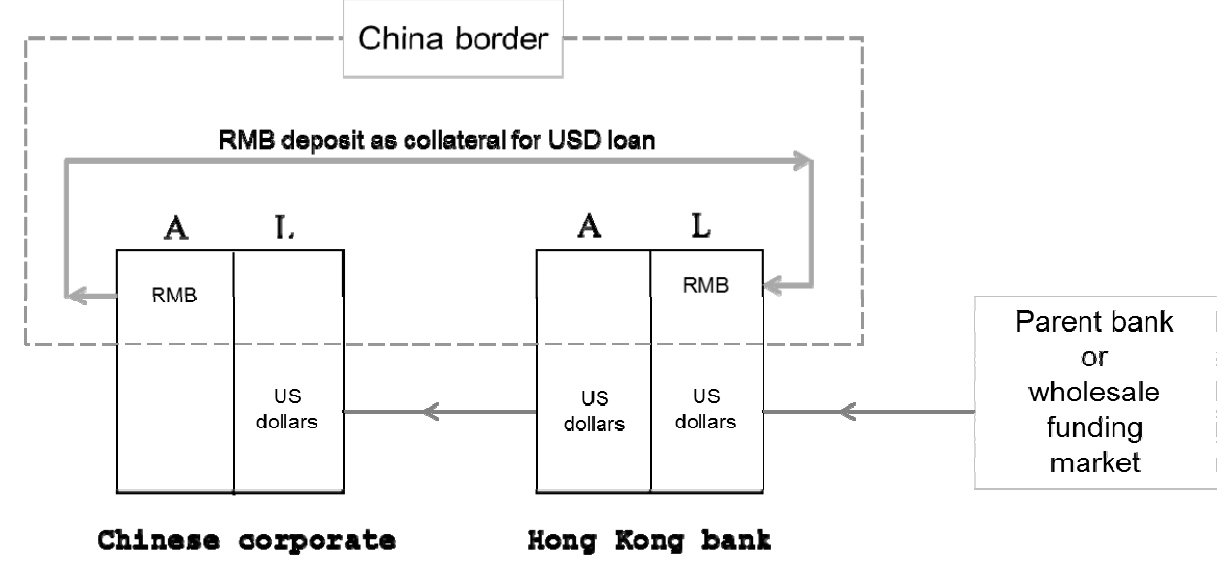

Figure 6 depicts the activities of a Chinese non-financial firm with operations outside China, who borrows in US dollars from an international bank in Hong Kong and posts renminbi deposits as collateral in the China office of the bank. The transaction would be akin to a currency swap, except that the settlement price is not chosen at the outset. The transactions instead resemble the operation of the old London Eurodollar market in the 1960s and 70s. For the Chinese corporate, the purpose of having US dollar liabilities and holding the proceeds in renminbi may be to hedge their export receivables, or simply to speculate on renminbi appreciation. In practice, the dividing line between hedging and speculation may be difficult to draw.

Figure 7 provides the evidence for the transactions depicted above in Figure 6. Figure 7 plots the claims and liabilities of Hong Kong banks in foreign currency to customers in China. Foreign currency, in this case, would be US dollars (mainly) for the assets and renminbi (mainly) for the liabilities. Both have risen dramatically in recent years, reflecting the rapidly increasing US dollar funding of non-financial corporates. 


\section{Figure 7. Hong Kong Banks' Claims and Liabilities to Nonbank Customers in China in Foreign Currency}

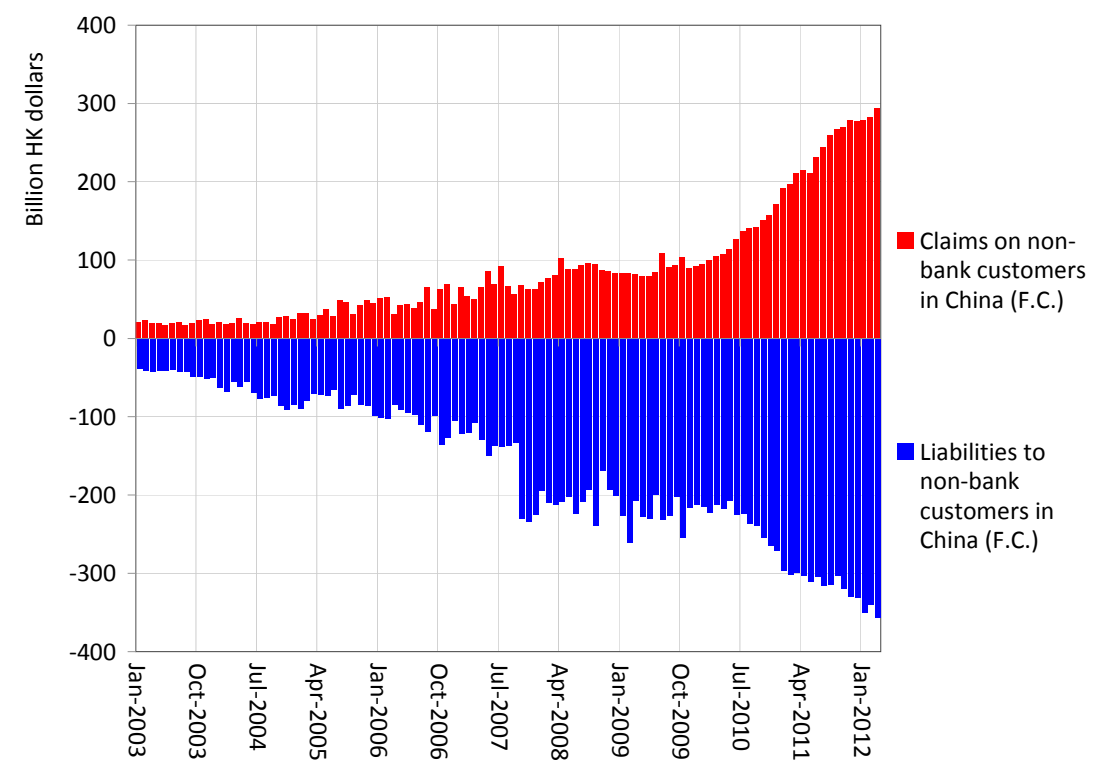

Source: Hong Kong Monetary Authority.

The procyclical pattern in corporate deposits in the right hand panel in Figure 3 may be due to such activities of non-financial corporates.

In addition, such activities of non-financial corporates may also explain why China has been experiencing dollar shortages in recent weeks with the deterioration of global funding markets due to the crisis in Europe. During this period the RMB has been under pressure, depreciating against the US dollar.

Although China's banking system is largely closed, the global activities of its non-financial firms will be reflected in the corporate deposits within M2 when those firms hold the proceeds of dollar liabilities in their accounts in China.

Figure 8 illustrates the growth in the component of the money stock that is due to the deposits of corporates, rather than for households. The left panel shows the time trend in personal deposits and corporate deposits, while the right panel shows the ratio of the corporate to personal deposits. We see the increase in proportion of corporate deposits in recent years, consistent with the operations of Chinese corporates as shown in Figure 6. 
Figure 8. Components of China's Monetary Aggregates
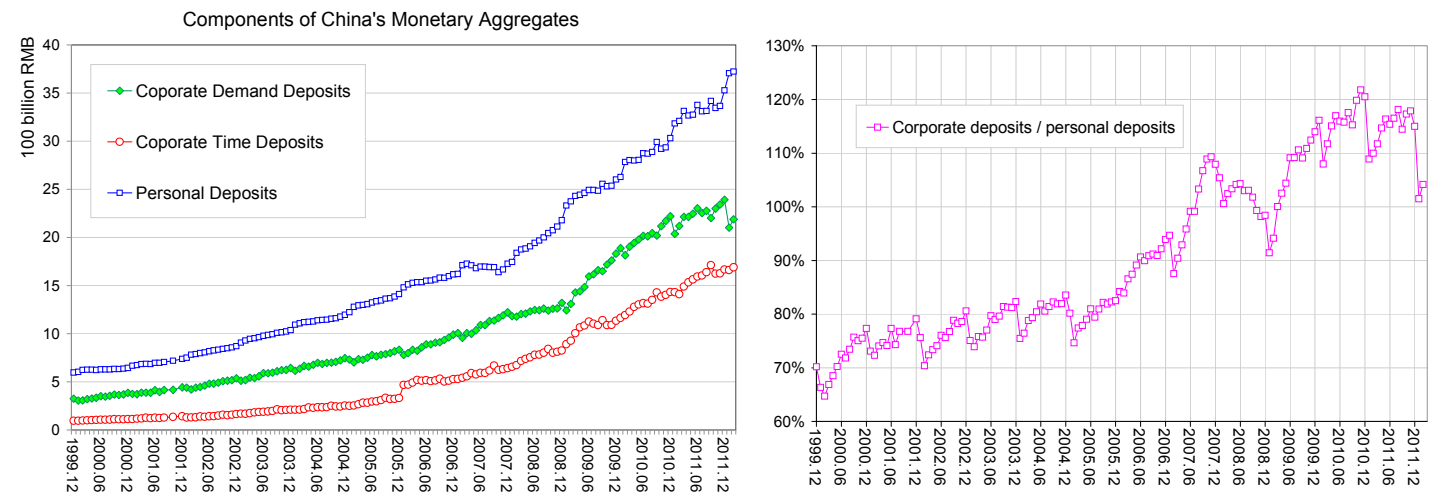

Source: People's Bank of China.

The excess liquidity generated by the activity of non-financial corporates in China will be an important element of the lending boom in China, and is reminiscent of the lending boom in Japan in the 1980s following financial liberalization that allowed Japanese companies to access global capital markets.

Both in Japan in the 1980s and in China more recently, monetary aggregates, especially corporate deposits played the role of non-core liabilities in the way that FX borrowing by Korean banks plays the role of non-core liabilities in Korea.

The point of contact between the FX liabilities in Korea and the corporate deposits in China is that both are liability components of banks. Provided we have the correct demarcation between core and non-core liabilities, we can apply the same method of tracking the ratio of non-core to core liabilities as an indicator that can serve as early warning indicators of financial vulnerability. 


\section{REFERENCES}

Basel Committee on Banking Supervision, 2009, "Strengthening the Resilience of the Banking Sector,” December, http://www.bis.org/publ/bcbs164.pdf.

Basel Committee on Banking Supervision, 2010, "International regulatory framework for banks (Basel III)," Bank for International Settlements, http://www.bis.org/bcbs/basel3.htm.

Berg, A., and C. Pattillo, 1999, “Are Currency Crises Predictable? A Test,” IMF Staff Papers, Vol. 46, No. 2, pp. 107-38.

Borio, C., and P. Lowe, 2002, “Asset Prices, Financial and Monetary Stability: Exploring the Nexus," BIS Working Paper 114.

Borio, C., and P. Lowe, 2004, "Securing sustainable price stability: should credit come back from the wilderness?" BIS Working Paper 157.

Calomiris, C., 1999, "Building an incentive-compatible safety net," Journal of Banking \& Finance, Vol. 23, No. 10, pp. 1499-519.

Chamon, M., and C. Crowe, 2012, "'Predictive' Indicators of Crises," in Handbook in Financial Globalization: The Evidence and Impact of Financial Globalization,ed. by G. Caprio (London: Elsevier), pp. 499-505.

Claessens, S., G. Dell'Ariccia, D. Igan, and L. Laeven, 2010, “Cross-Country Experiences and Policy Implications from the Global Financial Crisis," Economic Policy, Vol. 62, pp. 267-93.

Edge, R. M., and R.R. Meisenzahl, 2011, "The Unreliability of Credit-to-GDP Ratio Gaps in Real Time: Implications for Countercyclical Capital Buffers," International Journal of Central Banking, Vol. 7, pp. 261-98.

Goldstein, I., 2010, "Fundamentals or Panic: Lessons from the Empirical Literature on Financial Crises," Encyclopedia of Financial Globalization, forthcoming.

Hahm, J.-H., H.S. Shin, and K. Shin, 2013, "Non-Core Bank Liabilities and Financial Vulnerability," Journal of Money, Credit and Banking, 45(S1), pp. 3-36.

Himmelberg, C., C. Mayer, and T. Sinai, 2005, “Assessing High House Prices: Bubbles, Fundamentals, and Misperceptions,” NBER Working Paper No. 11643.

International Monetary Fund, 2010, The IMF-FSB Early Warning Exercise: Design and Methodological Toolkit, available at: www.imf.org/external/np/pp/eng/2010/090110.pdf.

Ivashina, V., and D. Scharfstein, 2010, "Bank lending during the financial crisis of 2008," Journal of Financial Economics, Vol. 97, pp. 319-38. 
Kaminsky, G., S. Lizondo, and C. Reinhart, 1998, "Leading Indicators of Currency Crisis," IMF Staff Papers, Vol. 45, No. 1, pp. 1-48.

Merler, S., and J. Pisani-Ferry, 2012, "Sudden Stops in the Euro Area,” Bruegel Policy Contribution, issue 2012/06.

Morris, S., and H.S. Shin, 1998, "Unique Equilibrium in a Model of Self-Fulfilling Currency Attacks," American Economic Review, Vol. 88, pp. 587-97.

Morris, S., and H.S. Shin, 2001, "Rethinking Multiple Equilibria in Macroeconomic Modelling,” NBER Macroeconomics Annual 2000, pp. 139-61.

Morris, S., and H.S. Shin, 2008, "Financial Regulation in a System Context," Brookings Papers on Economic Activity, Fall 2008, pp. 229-74.

Repullo, R., and J. Saurina, 2010, “The Countercyclical Capital Buffer of Basel III: A Critical Assessment," in The Crisis Aftermath: New Regulatory Paradigms, edited by Mathias Dewatripont and Xavier Freixas, Centre for Economic Policy Research, http://www.voxeu.org/sites/default/files/file/Crisis_Aftermath.pdf.

Shin, H.S., 2012, “Global Banking Glut and Loan Risk Premium,” IMF Economic Review, Vol. 60, pp. 155-92, Mundell-Fleming Lecture, IMF Annual Research Conference, November 2011.

Shin, H.S., and K. Shin, 2010, "Procyclicality and Monetary Aggregates," NBER Working Paper No. 16836.

Summers, L.H., 1985, “On Economics and Finance,” Journal of Finance, Vol. 40, No. 3, pp. 633-35. Papers and Proceedings of the 43rd Annual Meeting of the American Finance Association. 